\title{
A PLIOCENE FORAMINIFERID FAUNA FROM FLINDERS ISLAND, BASS STRAIT
}

\author{
by Patrick G. Quilty
}

(with one text-figure and one table)

QUILTY, P.G., 1985 (31:vii): A Pliocene foraminiferid fauna from Flinders Island, Bass Strait, Pap. Proc. R. Soc.

Tasm. 119:89-91. https://doi.org/10.26749/rstpp.119.89 ISSN 0080-4703. Antarctic Division,

Department of Science, Kingston, Tasmania.

A foraminiferid fauna from the Cameron Inlet Formation, Flinders Island, Tasmania is probably Late Pliocene in age. The benthic foraminiferid fauna has a strong Kalimnan aspect but the formation is probably a little younger than the stratotype Kalimnan.

Key Words: Foraminifera, Pliocene, Flinders Island.

\section{INTRODUCTION}

Sutherland and Kershaw (1971) summarised the Cainozoic geology of Flinders Island, and referred to the Cameron Inlet Formation as having variable lithology (predominantly glauconitic calcareous sand and silt) and seldom exceeding $7.5 \mathrm{~m}$ in thickness. It covers a considerable area of eastern and southeastern part of the island beneath a veneer of Quaternary sediments. They very effectively reviewed studies prior to that date and presented a comprehensive list of molluscs identified by previous authors, which provided a basis for assigning a Middle-Late Pliocene age to the faunas. In addition there was a reference to four species of foraminiferids identified by A.C. Collins and to an inner continental shelf environment of deposition based on the ratios of planktic to benthic foraminiferids identified by D.J. Taylor.

The present study is based on a sample of the Cameron Inlet Formation collected in 1980 at Warren's Farm, North Patriarch dragline drain (39 58'S: $148^{\circ} 07^{\prime} \mathrm{E}$; fig. 1) by Dr F.L. Sutherland, Australian Museum, Sydney. The sample supplied consists of a very friable, slightly weathered, very poorly sorted, highly calcareous sandstone with abundant molluscan(particularlybivalve) remains, many unbroken. All aspects are of a very shallow, quiet water environment of deposition, perhaps in a marine lagoon.

Quilty (1972) summarised knowledge of the Tertiary stratigraphy of Tasmania based on foraminiferid studies and recorded no good faunas younger than Early Miocene but later (1985) described a Pliocene fauna dredged from the sea floor off St Helens in northeastern Tasmania

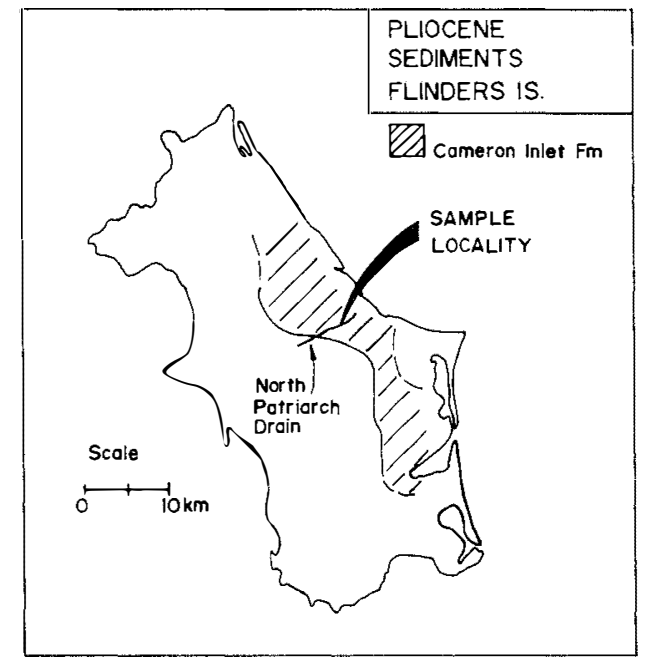

FIG. 1 - Locality Map

\section{FORAMINIFERIDA AND CORRELATION}

The benthic fauna (table 1) is very similar to that described by Carter (1964) from the onshore Jemmys Point Formation of the Gippsland Basin. Common important benthic foraminiferids include Valvulineria kalimnensis, Florilus (Nonion of Carter) victoriensis, Astrononion tasmaniensis, Elphidium imperatrix. These perhaps suggest that while age may be similar, environment of deposition controls the very great benthic similarity. The fauna does allow correlation with the Kalimnan of 


\title{
TABLE 1 \\ FORAMINIFERIDA, CAMERON INLET FORMATION, FLINDERS ISLAND Benthic Foraminiferids
}

\author{
Valvulineria kalimnensis (Parr) \\ Lagena spp \\ Elphidium pseudonodosum Cushman \\ Discorbinella bertheloti(d'Orbigny) \\ Fissurina spp \\ Cibicides thiara Stache \\ Astrononion tasmaniensis Carter \\ Guttulina communis (d'Orbigny) \\ Rosalina mitchelli Carter \\ $R$. sp. \\ Anomalinoides sp. \\ Elphidium imperatrix (Brady) \\ E. macellum (Fichtel \& Moll) \\ Notorotalia howchini (Chapman, Parr \\ \& Collins) \\ Quinqueloculina seminulum (Linnaeus) \\ Pyrulina angusta (Egger) \\ Pileolina aff. australensis (H.A.\& E.) \\ Florilus victoriensis (Cushman) \\ Elphidium chapmani Cushman \\ Gyroidina neosoldanii Brotzen \\ 13 Sigmoidella elegantissima (Parker \& Jones) \\ 9 Lenticulina sp. \\ 7 Guttulina regina (Brady, Parker \& Jones) \\ 7 Oolina sp. \\ $5 \quad$ Pileolina sp. \\ 5 Crespinella sp. \\ 3 Elphidium crassatum Cushman \\ 3 E. jenseni (Cushman) \\ 3 Siphotextularia cf. concava (Karrer) \\ 3 Quinqueloculina intricata Terquem \\ $3 \quad$ Q. ?venusta Karrer \\ 3 Q. lamarckiana d'Orbigny \\ 2 Guttulina pacifica (Cushman \& Ozawa) \\ Polymorphina sp. \\ Bolivina sp. \\ Cancris sp. \\ Pileolina wiesneri (Parr) \\ Discorbinella planoconcavata (C.P.\& C.) \\ Planulinoides biconcavus (Jones \& Parker)
}

\section{$\%$}

\section{Planktic foraminiferids}

Globigerina bulloides d'Orbigny

Turborotalita quinqueloba (Natland)

Globorotalia (Truncorotalia) crassaformis

crassaformis (Galloway \& Wissler)

Neogloboquadrina pachyderma

(Ehrenberg)
G. (Truncorotalia) crassaformis ronda Blow

Globigerina rubescens decoraperta

Takayanagi \& Saito

Globorotalia (Truncorotalia) inflata (d'Orbigny)

Globigerina pachyderma (Ehrenberg) form 1 of Keller 1978

$\%$ indicates percentage of benthic or planktic species respectively

\section{Planktic Percentage 23}

Singleton (1941) in the southeastern Australian Tertiary in benthic (and thus dominantly environmental) terms.

While the planktic fauna makes up $23 \%$ of the total, diversity is low and many key forms in major zonal schemes (e.g. that of Blow, 1969) are absent. This fauna lacks keeled globorotaliids, sphaeroidinellids, pulleniatinids and Globigerinoides. Species present include Globorotalia inflata $G$. crassaformis, Globigerina bulloides and $G$. rubescens decoraperta. These allow correlation with Blow's $\mathrm{N} 20$ or N21, that is mid or Late Pliocene, although for reasons given below, the Late Pliocene age is preferred.
The Kalimnan age determination for the Cameron Inlet Formation based on foraminiferids could be seen as being in conflict with the age based on molluscs which suggest an age slightly younger than Kalimnan (Darragh and Kendrick, 1971) because of the high proportion of living species therein. Darragh and Kendrick suggested a "Middle to Upper Pliocene" age. Darragh (1985) referred the Cameron Inlet Formations mollusc fa una to his Molluscan Assemblage XVII and regarded it as Late Pliocene, noting that no diagnostic foraminiferids have been recovered and that no southeastern Australian stage name is appropriate. 
The foraminiferid fauna, as noted above, is one likely to be largely environmentally controlled (as could be expected also of the molluscs) but has a strong Kalimnan aspect. Abele et al. in Douglas and Ferguson (1976) took the Kalimnan to correlate approximately with zones N19 or N20 of Blow's (1969) scheme. The correlation suggested above with $\mathrm{N} 20$ or $\mathrm{N} 2 \mathrm{l}$ is consistent with the molluse evidence and with the Late Pliocene age determination. It is thus either post Kalimnan or perhaps partly overlapping with the later Kalimnan.

The Gippsland Basin contains in its offshore part the only apparently continuous Pliocene to Recent marine sequence so far encountered in southeastern Australia. Hocking (1972) referred all units of the Pliocene-Recent, although lithologically not sandstone, to the Jemmys Point Formation. Onshore, the section consists of a discontinuous sequence including marine sections such as sandstone of the Jemmys Point Formation, grading upwards into non-marine sediments and including several hiatuses.

Abele in Douglas and Ferguson (1976) recognised only Early (Zanclian) and Late (Piacenzian) in the Pliocene of Victoria. The Kalimnan appears to straddle the boundary between the two stages but its boundaries remain ill defined involving species not identified here. Planktic species recorded here do not allow correlation with the scheme proposed by Abele as Globorotalia acostaensis is absent from the Flinders Island section.

\section{ENVIRONMENT OF DEPOSITION}

The 23\% planktic content suggests inner to middle continental shelf depth of deposition. The absence of Ammonia beccarii - whose presence is a feature of the type Kalimnan - is consistent with fully marine conditions.

The groups listed above as absent are all associated with warm water conditions. Their absence is negative evidence consistent with either cool or very shallow water conditions (or both). It is unlikely in the inferred conditions of deposition that the apparent absence is not real. Thus the sample is taken as representing deposition in cool conditions.

An explanation for the apparent cool water aspect of the fauna is that it is younger than the mid - Pliocene fauna recorded in the accompanying paper (Quilty 1985). That fauna probably represents the last warm water phase before the initiation of what became the Pleistocene glaciation.

\section{COMPARISON WITH OTHER TASMANIAN SECTIONS}

Quilty (1985) has recorded a warmer water Pliocene fauna from the east coast, off shore from St Helens; the two samples representing Tasmania's only known Pliocene. The other fauna, in addition to this, suggests that Tasmania has a patchy Neogene sediment record but one which includes evidence of a change from a warm mid-Pliocene to cool water Late Pliocene in eastern Tasmania.

\section{SAMPLES AND ACKNOWLEDGEMENTS}

A representative sample of the foraminiferids is held in the collection of the University of Tasmania, Geology Department as specimen number UTGD 122867. The author is indebted to Dr F.L. Sutherland Australian Museum Sydney, for providing the sample and to Dr T. Darragh, National Museum of Victoria, Melbourne, for helpful discussions.

\section{REFERENCES}

BLOW, W.H., 1969: Late Middle Eocene to Recent planktonic foraminiferal biostratigraphy. Proc. 1st Intern'l Conf. Planktonic Microfossils, Geneva 1: 199-422, pls. 1-54.

CARTER, A.N., 1964: Tertiary foraminifera from Gippsland, Victoria and their stratigraphical significance. Mem. geol. Surv. Vict. 23: 1-154, pls. $1-17$.

DARRAGH, T.A., 1985: Molluscan biogeography and biostratigraphy of the Tertiary of southeastern Australia. Alcheringa, 9:83-116.

DARRAGH, T.A. \& KENDRICK, G.W., 1971: Zenatiopsis ultima sp. nov., terminal species of the Zenatiopsis lineage (Bivalvia: Mactridae) Proc. R.Soc.Vict., 84: 87-92.

DOUGLAS, J.G. \& FERGUSON, J.A., (Eds) 1976: GEOLOGY OF VICTORIA. Spec. Publ. Geol. Soc. Aust. 5: 1-528.

HOCKING, J.B., 1972: Geological evolution and hydrocarbon habitat Gippsland Basin. Aust. Petrol. Explor. Assoc. J., 12: 132-137.

QUILTY,P.G., 1972: The stratigra phy of the Tasmanian marine Tertiary. Pap. Proc. R. Soc. Tasm., 106: 25-44.

QUILTY, P.G., 1985: Miocene and Pliocene sediments dredged from the sea floor off St Helens, northeastern Tasmania. Pap. Proc. R. Soc. Tasm., 119:000-000.

SINGLETON, F.A., 1941: The Tertiary geology of Australia Proc. R. Soc. Vict., 53: 1-125.

SUTHERLAND, F.L., AND KERSHAW, R.C., 1971: The Cainozoic geology of Flinders Island, Bass Strait. Pap. Proc. R. Soc. Tasm., 105: 15 $1-175$. 